\title{
Deposition of Cerium-Based Conversion Coatings on Aluminum Alloy 380
}

\author{
Ci Lin, Surender Maddela, William G. Fahrenholtz, and Matthew J. O’Keefe \\ Materials Research Center and Department of Materials Science and Engineering, Missouri University of Science \& Technology, \\ Rolla, MO 65409, USA
}

Correspondence should be addressed to William G. Fahrenholtz, billf@mst.edu

Received 11 May 2012; Revised 18 July 2012; Accepted 23 July 2012

Academic Editor: Ingrid Milošev

Copyright (๑) $2012 \mathrm{Ci}$ Lin et al. This is an open access article distributed under the Creative Commons Attribution License, which permits unrestricted use, distribution, and reproduction in any medium, provided the original work is properly cited.

Cerium-based conversion coatings were deposited on as-cast aluminum alloy 380 substrates by a spontaneous immersion process. In this study, the effects of rinsing temperature prior to immersion in the coating deposition solution were studied with respect to the surface morphology, electrochemical response, and corrosion resistance of the coatings. Panels rinsed at $25^{\circ} \mathrm{C}$ prior to coating had large cracks and holes in the coating. In contrast, panels rinsed at $100^{\circ} \mathrm{C}$ prior to coating had a uniform coating morphology with fewer, smaller cracks. Electrochemical testing revealed that coatings deposited on substrates rinsed at $100^{\circ} \mathrm{C}$ had higher impedance $\left(\sim 80 \mathrm{k} \Omega \cdot \mathrm{cm}^{2}\right)$ and lower corrosion current $\left(\sim 0.34 \mu \mathrm{A} / \mathrm{cm}^{2}\right)$ compared to coatings deposited on substrates rinsed at $25^{\circ} \mathrm{C}$, which had $10 \mathrm{k} \Omega \cdot \mathrm{cm}^{2}$ impedance and $2.7 \mu \mathrm{A} / \mathrm{cm}^{2}$ corrosion current. Finally, ASTM B117 salt spray testing showed that rinsing at $100^{\circ} \mathrm{C}$ prior to coating resulted in cerium-based conversion coatings that could resist the formation of salt tails for at least 8 days.

\section{Introduction}

Aluminum cast alloys are widely used in the automotive and aerospace industries where innovative, lightweight materials and product forms are needed to improve performance [1]. Common aluminum casting alloys contain alloying additives that affect the mechanical properties, fluidity, and corrosion resistance [2]. For example, the 3xx.x series contain noble alloying elements such as $\mathrm{Si}$ and $\mathrm{Cu}$ that can promote pitting corrosion and lead to the failure of aluminum alloy components [3].

Chromate conversion coatings are used for corrosion protection for a wide variety of aluminum alloy components [4]. However, the toxicity and carcinogenic properties of hexavalent chromium $\left(\mathrm{Cr}^{6+}\right)$ have caused severe restrictions to be imposed on the use of chromates [5-7]. As a result, environmentally benign alternatives to chromates have been extensively investigated [8]. Potential replacements for chromate conversion coatings include anodized coatings [9], rare-earth-based inhibitors in conversion coatings [10], and sol-gel coatings [11]. Among potential chromate replacements, rare-earth inhibitors have attracted significant attention. Hinton et al. were the first to investigate cerium-based conversion coatings (CeCCs) as an environmentally benign alternative to chromate conversion coatings $[12,13]$.

The corrosion resistance of CeCCs is thought to arise from a combination of barrier properties and active response to the environment $[14,15]$. The barrier protection properties of CeCCs have been studied by changing processing parameters, specifically surface preparation $[16,17]$, posttreatment [18], and the use of gelatin [19]. The corrosion resistance of CeCCs on high-strength aluminum alloys has been optimized through screening studies that have examined variables such as cerium concentration, $\mathrm{pH}$ of the deposition solution, and hydrogen peroxide concentration [20,21]. The composition of the spray deposition solution used in the present research is based on the work of Pinc et al. [19] that exhibited the best corrosion resistance on Al 2024-T3.

Previous studies have focused on the deposition mechanisms of CeCCs from cerium chloride solutions onto aluminum alloy substrates. Hinton and Wilson [22] speculated that many electrochemical cells would arise due to the different activities of intermetallic particles on the surface of an aluminum alloy when the alloy was immersed into the solution. When immersed, anodic dissolution as expressed 
TABle 1: Nominal compositions of Al alloy 380 [1].

\begin{tabular}{lcccccccccc}
\hline Element & $\mathrm{Si}$ & $\mathrm{Fe}$ & $\mathrm{Cu}$ & $\mathrm{Mn}$ & $\mathrm{Mg}$ & $\mathrm{Ni}$ & $\mathrm{Zn}$ & $\mathrm{Sn}$ & $\mathrm{Other}$ & $\mathrm{Al}$ \\
\hline wt $\%$ & $7.5-9.5$ & 2.0 & $3.0-4.0$ & 0.50 & 0.10 & 0.50 & 3.0 & 0.35 & 0.50 & Balance \\
\hline
\end{tabular}

by Reaction (1) could occur at different locations according to the inhomogeneous surface activity.

$$
\mathrm{Al} \longrightarrow \mathrm{Al}^{3+}+3 \mathrm{e}^{-} .
$$

As $\mathrm{Al}$ dissolves, the corresponding cathodic reaction could be hydrogen evolution (Reaction (2)), the reduction of peroxide (Reaction (3)), and/or reduction of oxygen dissolved in solution (Reaction (4)):

$$
\begin{gathered}
2 \mathrm{H}^{+}+2 \mathrm{e}^{-} \longrightarrow \mathrm{H}_{2} \\
\mathrm{H}_{2} \mathrm{O}_{2}+2 \mathrm{H}^{+}+2 \mathrm{e}^{-} \longrightarrow 2 \mathrm{H}_{2} \mathrm{O} \\
\mathrm{O}_{2}+4 \mathrm{H}^{+}+4 \mathrm{e}^{-} \longrightarrow 2 \mathrm{H}_{2} \mathrm{O}
\end{gathered}
$$

The $\mathrm{pH}$ in the electrolyte near local cathodic sites increases as the electrode reactions proceed. At $\mathrm{pH}$ values lower than 2.5, $\mathrm{H}_{2} \mathrm{O}_{2}$ complexes with $\mathrm{Ce}(\mathrm{III})$ species in solution as $\mathrm{Ce}\left(\mathrm{H}_{2} \mathrm{O}_{2}\right)^{3+}$, and with increasing $\mathrm{pH}$ values (2.5 to 3.3) through deprotonating steps peroxo species form $\mathrm{Ce}\left(\mathrm{O}_{2}\right)^{2+}$ and when the $\mathrm{pH}$ value reaches $6.5 \mathrm{Ce}\left(\mathrm{O}_{2}\right)^{2+}$ transforms to $\mathrm{Ce}\left(\mathrm{O}_{2}\right)(\mathrm{OH})_{2}[23,24]$. In the deposition process, $\mathrm{H}_{2} \mathrm{O}_{2}$ acts as a complexing agent, oxidant, crystallization inhibitor, and $\mathrm{OH}^{-}$generator [24].

The purpose of this paper is to investigate the deposition of cerium-based conversion coatings on cast aluminum alloy 380 (AA 380). The effects of pretreatment and the temperature of the panel before immersion on coating morphology, electrochemical response, and corrosion resistance were investigated.

\section{Experimental Procedure}

Aluminum alloy 380 sheets $0.3 \mathrm{~cm}$ thick were cut into test panels $2.5 \mathrm{~cm}$ by $7.6 \mathrm{~cm}$ in size. The nominal composition of AA 380 is summarized in Table 1 [1]. Pretreatment of the panels prior to coating started with an isopropyl alcohol wipe followed by degreasing in an aqueous solution of a commercial alkaline cleaner ( $5 \mathrm{wt} \%$ Turco $4215 \mathrm{NC}$-LT in deionized water) for 5 minutes at $55^{\circ} \mathrm{C}$. After degreasing, the panels were activated by immersion for $10 \mathrm{~min}$ at $50^{\circ} \mathrm{C}$ in an aqueous solution containing $1 \mathrm{wt} \%$ sulfuric acid. Following cleaning and activation, the panels were rinsed in deionized water that was either at room temperature (nominally $25^{\circ} \mathrm{C}$ ) or heated to $100^{\circ} \mathrm{C}$ for about 1 minute. After rinsing, the panels were immersed in the deposition solution for different time intervals of up to $8 \mathrm{~min}$.

The CeCC deposition solution was prepared from a stock solution consisting of $40 \mathrm{~g} \mathrm{CeCl}_{3} \cdot x \mathrm{H}_{2} \mathrm{O}$ (Alfa Aesar, 99.9\%) and $780 \mathrm{~g}$ of deionized water. The $\mathrm{pH}$ of the solution was adjusted to 2.07 with $\mathrm{HCl}$ after dissolution of the cerium chloride. For the deposition solution, $205 \mathrm{~g}$ of the stock solution was mixed with $0.8 \mathrm{~g}$ of a water soluble gelatin (DSF,
Rousselot) that was dissolved in $25 \mathrm{~g}$ of deionized water. Just before deposition, $15 \mathrm{~mL}$ of $\mathrm{H}_{2} \mathrm{O}_{2}$ (Fisher Chemical, $30 \mathrm{wt} \%$ ) was added.

Coated panels were posttreated by immersion for $5 \mathrm{~min}$ utes in a water solution containing $2.5 \mathrm{wt} \% \mathrm{Na}_{3} \mathrm{PO}_{4}(\mathrm{pH}$ adjusted to 4.5 with phosphoric acid) that was heated to $85^{\circ} \mathrm{C}$. Posttreatment converts the as-deposited hydrated cerium oxide phase to hydrated cerium phosphate, which has superior corrosion protection $[14,18]$. The corrosion resistances of the coated panels were evaluated using salt spray testing (Q-Fog, Q-Panel Lab Products) per ASTM standard B117. Panels with CeCCs were stored at room temperature in the laboratory for at least $24 \mathrm{~h}$ before characterization or salt spray testing.

Scanning electron microscopy (SEM; Hitachi S-4700) with energy dispersive X-ray spectroscopy (EDS; Phoenix System) was used to characterize the surface morphologies and compositions of CeCCs. Coating thicknesses were determined from cross-sections of coated panels that were produced by focus ion beam milling in a dual column instrument (FIB; FEI Helios NanoLab 600).

Electrochemical impedance spectroscopy (EIS) was carried out at open-circuit potential with amplitude of $10 \mathrm{mV}$ in the frequency range from $10^{5}$ to $10^{-2} \mathrm{~Hz}$. Measurements were made after stabilization in the test electrolyte for 1500 s. All experiments were conducted with a frequency response analyzer (Schlumberger SI $1255 \mathrm{HF}$ ) coupled with a potentiostat/galvanostat (EG\&G Princeton Applied Research Model 273A). Spectra were fit to equivalent circuit models to determine coating characteristics including coating impedance $\left(R_{P}\right)$ according to previously reported methods $[25,26]$. Potentiodynamic polarization measurements were carried out after EIS, the initial potential was $-400 \mathrm{mV}_{\mathrm{SCE}}$ and final potential is $800 \mathrm{mV}_{\mathrm{SCE}}$ with respect to the opencircuit potential, and the scan rate was $1 \mathrm{mV} / \mathrm{sec}$. A standard flat cell (EG\&G Princeton Applied Research) was used for the electrochemical polarization measurements. The cell electrolyte was a modified prohesion solution, which consisted of $0.70 \mathrm{wt} \%\left(\mathrm{NH}_{4}\right)_{2} \mathrm{SO}_{4}$ and $0.35 \mathrm{wt} \% \mathrm{NaCl}$ in deionized water. Specimens were tested at the natural $\mathrm{pH}$ of the solution, which was about 5.5. The exposed area of the working electrode was $1 \mathrm{~cm}^{2}$. A saturated calomel electrode (SCE) was used as the reference electrode and Pt mesh was used as the counter electrode. Open-circuit potential $\left(E_{\text {corr }}\right)$ and corrosion current $\left(I_{\text {corr }}\right)$ were determined by the Tafel fit method using CorrView and ZView software (Scribner Associates) as previously reported [18].

\section{Results and Discussion}

3.1. Effect of Pretreatment. Aluminum alloy 380 is composed of several different phases including the $\mathrm{Al}$ matrix phase, a major second phase of $\mathrm{Si}$, and trace intermetallic phases 


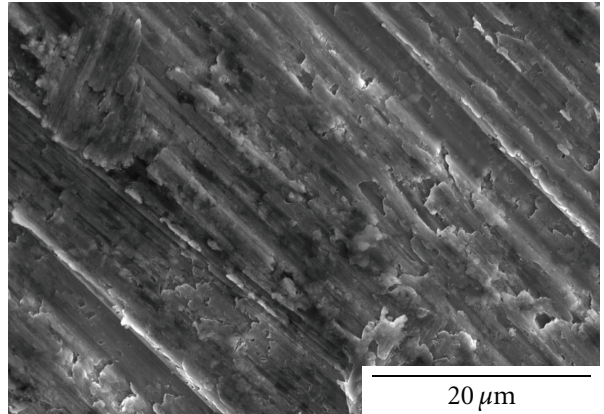

(a)

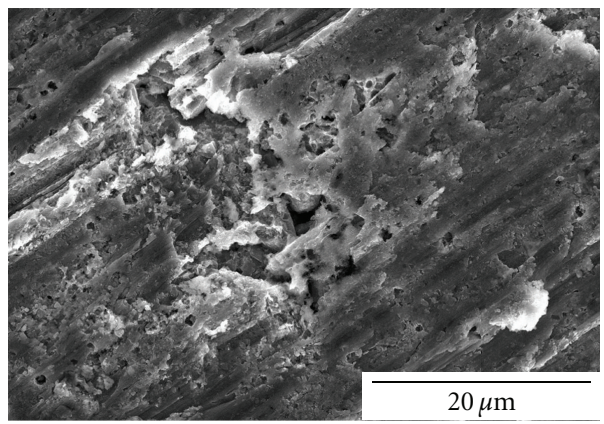

(c)

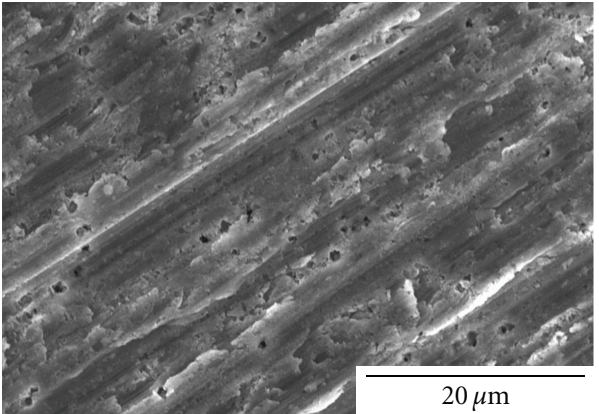

(b)

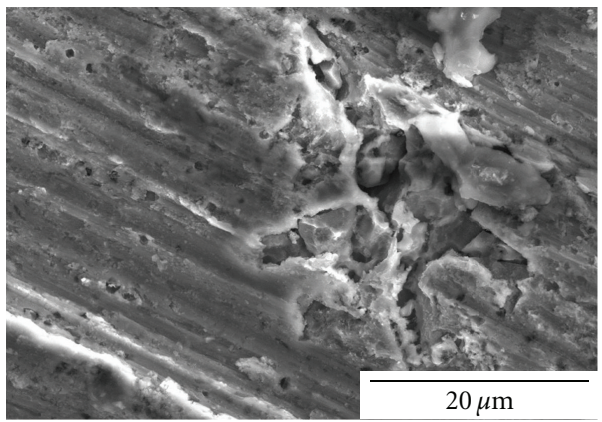

(d)

Figure 1: SEM surface morphology of AA 380 panels after alkaline cleaning and acid activation and (a) polishing with 180 grit abrasive paper, (b) water rinsing at $25^{\circ} \mathrm{C}$, (c) water rinsing at $25^{\circ} \mathrm{C}$ showing an area with removal of material, and (d) water rinsing at $100^{\circ} \mathrm{C}$.

such as $\mathrm{Al}_{2} \mathrm{Cu}, \mathrm{FeSi}_{2}$, and $\mathrm{Al}_{4.5} \mathrm{FeSi}$. Analysis of surface morphology (Figures 1(a) and 1(b)) and chemistry of the substrate after pretreatment revealed that intermetallic particles containing Fe and Si were dissolved by the alkaline or acid pretreatments. Dissolution sometimes left holes in the substrates that were up to about $20 \mu \mathrm{m}$ in diameter (Figures $1(\mathrm{c})$ and $1(\mathrm{~d}))$. No discernible differences in surface morphology were observed for panels that had been rinsed with water at room temperature or $100^{\circ} \mathrm{C}$.

Pretreatment altered the electrochemical response of the substrates. From the potentiodynamic curves shown in Figure 2(a), pretreatment increased the open-circuit potential from about $-600 \mathrm{mV}_{\mathrm{SCE}}$ for the starting panel to about $-500 \mathrm{mV}_{\mathrm{SCE}}$ after alkaline cleaning, acid activation, and rinsing. Figure 2(a) also shows that the pretreatment increased the corrosion current from $0.3 \mu \mathrm{A} / \mathrm{cm}^{2}$ before pretreatment to $2.0 \mu \mathrm{A} / \mathrm{cm}^{2}$ after pretreatment. However, the rinsing temperature, $25^{\circ} \mathrm{C}$ or $100^{\circ} \mathrm{C}$, did not produce significant differences in either the open-circuit potential or the corrosion current. The increase in corrosion current after pretreatment indicated that the alloy surface was more electrochemically active, which made the panels easier to coat. From the corresponding electrochemical impendence spectra (Figure 2(b)), the impedance of the starting panel was around $40 \mathrm{k} \Omega \cdot \mathrm{cm}^{2}$, which was much larger than the impedance after pretreatment $\left(\sim 7.5 \mathrm{k} \Omega \cdot \mathrm{cm}^{2}\right.$ for both rinsing temperatures). Based on comparisons to the results of previous studies [27], the pretreatment process likely reduced the thickness of the native oxide layer, which decreased the impedance of the substrate. Previous analysis showed that the reduction in
TABLe 2: Electrochemical parameters derived from potentiodynamic polarization measurements and impedance spectra.

Corrosion parameters

Immersion time ( $\min ) R_{p}\left(\mathrm{k} \Omega \cdot \mathrm{cm}^{2}\right) I_{\text {corr }}\left(\mu \mathrm{A} / \mathrm{cm}^{2}\right) E_{\text {corr }}\left(\mathrm{mV}_{\mathrm{SCE}}\right)$

\begin{tabular}{lcccccc} 
& $25^{\circ} \mathrm{C}$ & $100^{\circ} \mathrm{C}$ & $25^{\circ} \mathrm{C}$ & $100^{\circ} \mathrm{C}$ & $25^{\circ} \mathrm{C}$ & $100^{\circ} \mathrm{C}$ \\
\hline 2 & 32 & 36 & 0.82 & 0.73 & -540 & -480 \\
5 & 16 & 49 & 1.60 & 0.54 & -550 & -480 \\
8 & 10 & 76 & 2.70 & 0.34 & -510 & -540 \\
\hline
\end{tabular}

impedance and increase in corrosion current were necessary to promote deposition of CeCCs [27].

3.2. Electrochemical Behavior of CeCCs. For substrates rinsed at $25^{\circ} \mathrm{C}$ prior to coating deposition, increasing the immersion time in the coating solution made the surface more electrochemically active (values summarized in Table 2). From the potentiodynamic curves in Figure 3(a), the corrosion current increased from $0.82 \mu \mathrm{A} / \mathrm{cm}^{2}$ after two minutes in the coating solution to $1.6 \mu \mathrm{A} / \mathrm{cm}^{2}$ after 5 minutes and $2.7 \mu \mathrm{A} / \mathrm{cm}^{2}$ after eight minutes. In contrast, the open-circuit potential did not vary significantly among the three panels, with all having values around $-530 \mathrm{mV}_{\text {SCE}}$. The increasing corrosion current with the increasing immersion time suggests that the surface of the AA 380 is more susceptible to chloride attack and dissolution. Therefore, for substrates rinsed at $25^{\circ} \mathrm{C}$, increasing the immersion time appears to increase attack of the substrate by chloride ions in the coating solution. 


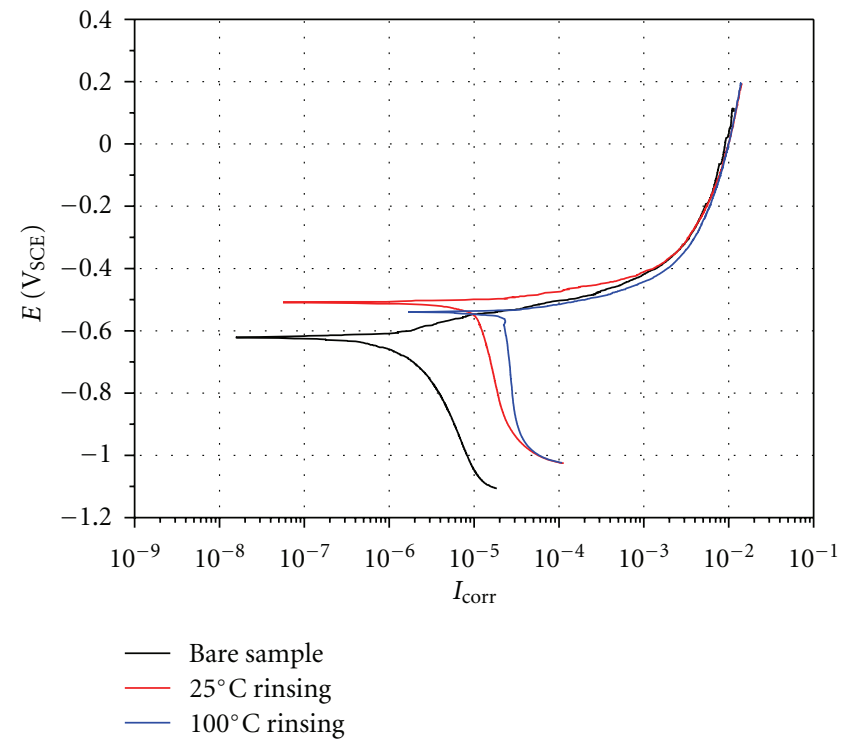

(a)

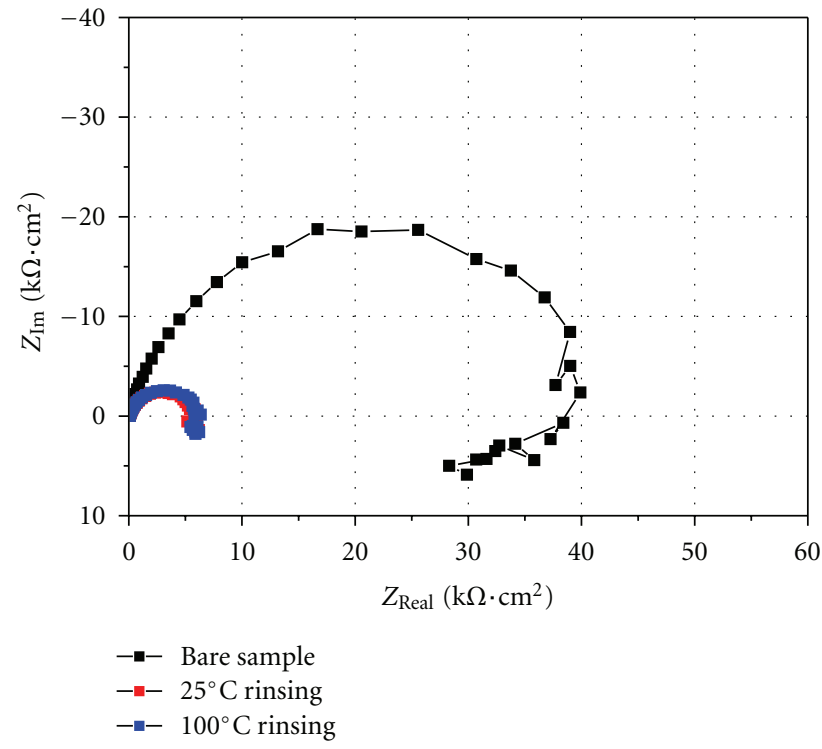

(b)

Figure 2: (a) Potentiodynamic polarization curves and (b) impedance spectroscopy of AA 380 panels before pretreatment (bare) and after rinsing at $25^{\circ} \mathrm{C}$ and $100^{\circ} \mathrm{C}$.

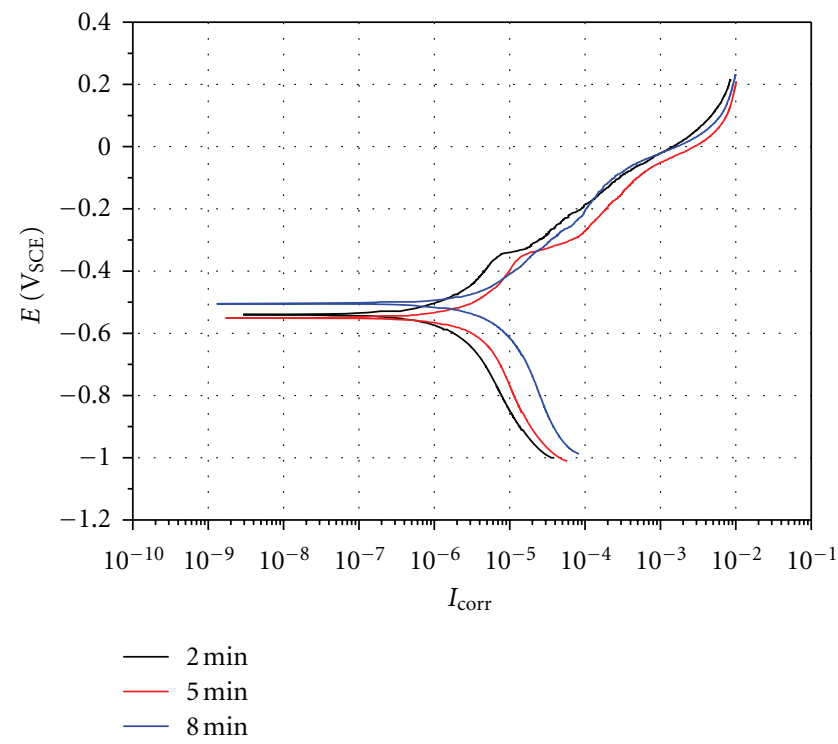

(a)

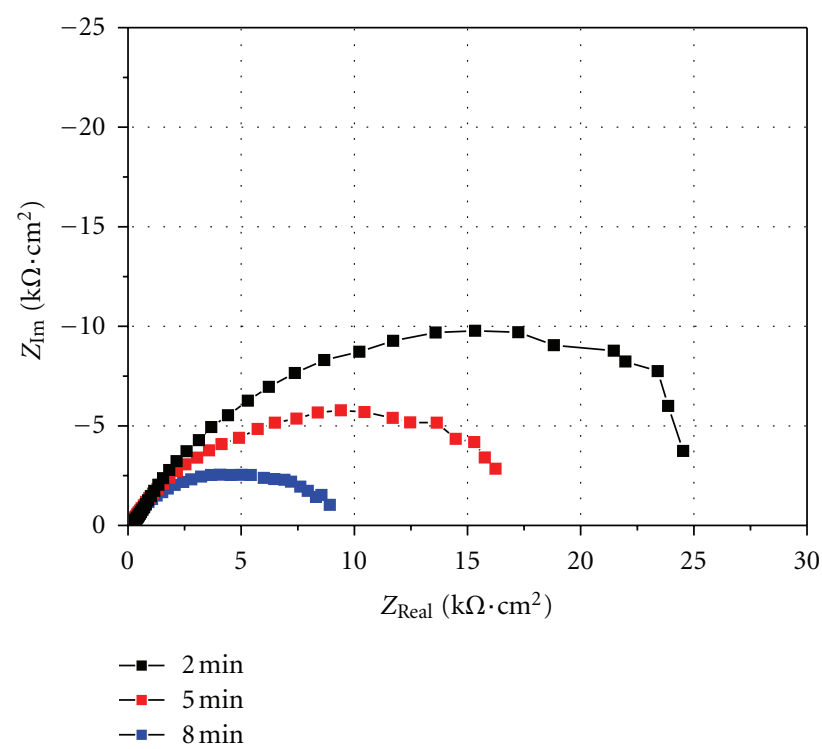

(b)

FIgURe 3: (a) Potentiodynamic polarization curves and (b) impedance spectra for CeCCs deposited AA 380 substrates rinsed at $25^{\circ} \mathrm{C}$ as a function of coating deposition time.

For substrates rinsed at $100^{\circ} \mathrm{C}$ prior to coating deposition, increasing the immersion time in the coating solution increased the corrosion resistance (values summarized in Table 2). The potentiodynamic curves shown in Figure 4(a) reveal that the corrosion current decreased from $0.73 \mu \mathrm{A} / \mathrm{cm}^{2}$ after immersion for 2 minutes to $0.54 \mu \mathrm{A} / \mathrm{cm}^{2}$ after five minutes and to $0.34 \mu \mathrm{A} / \mathrm{cm}^{2}$ after eight minutes. The open circuit potential was about the same after immersion in the deposition solution for 2 or 5 minutes $\left(-480 \mathrm{mV}_{\mathrm{SCE}}\right)$, but decreased to about $-540 \mathrm{mV}_{\mathrm{SCE}}$ after immersion for eight minutes. The decreasing corrosion current indicated that the coatings had better corrosion resistance as the immersion time increased. Compared to panels rinsing at $25^{\circ} \mathrm{C}\left(0.82 \mu \mathrm{A} / \mathrm{cm}^{2}\right)$, rinsing at $100^{\circ} \mathrm{C}$ for 2 minutes resulted in a coating with better corrosion resistance $\left(0.73 \mu \mathrm{A} / \mathrm{cm}^{2}\right)$ and the corrosion resistance, as measured by corrosion current, continued to increase as deposition time increased. Therefore, rinsing at $100^{\circ} \mathrm{C}$ prior to coating deposition 


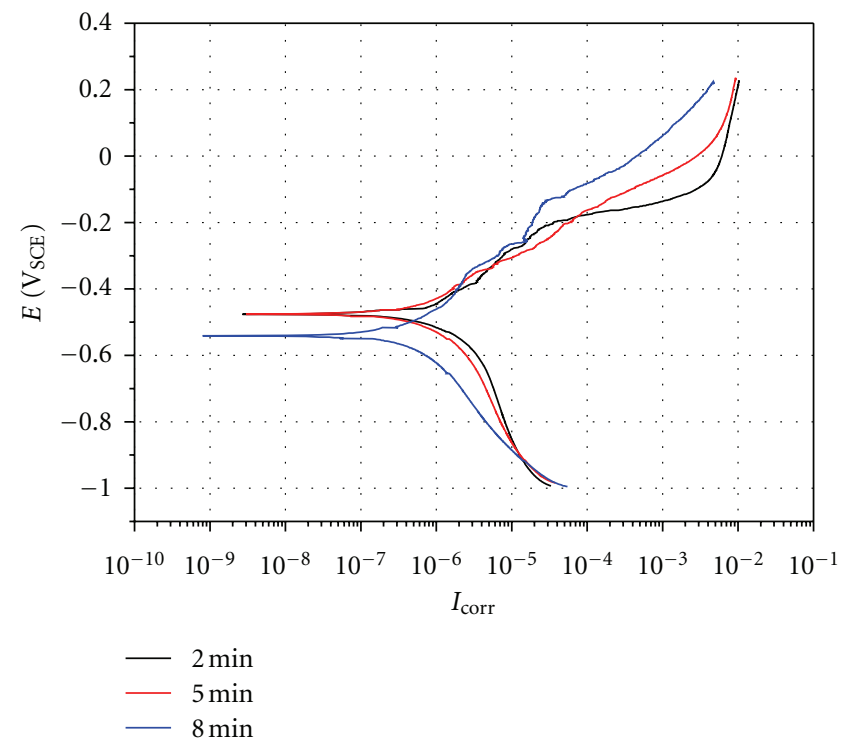

(a)

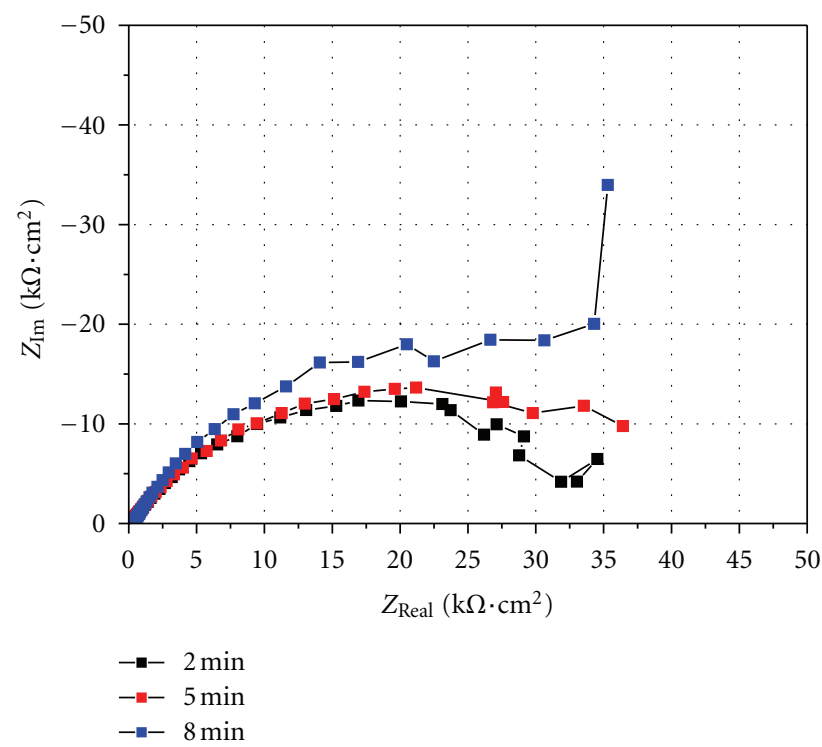

(b)

FIgure 4: (a) Potentiodynamic polarization curves and (b) impedance spectra for CeCCs deposited AA 380 substrates rinsed at $100^{\circ} \mathrm{C}$ as a function of coating deposition time.

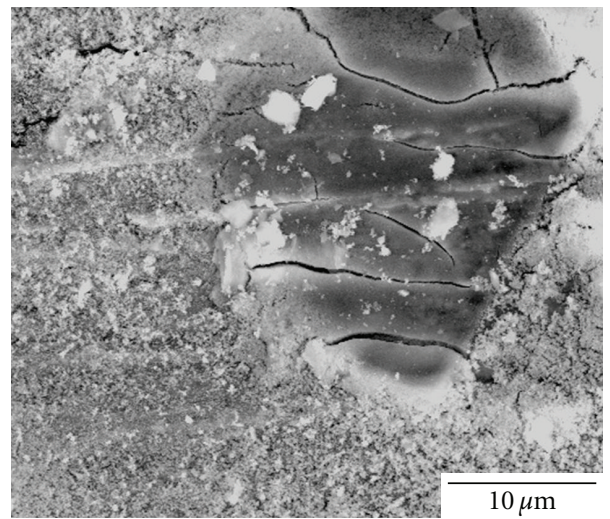

(a)

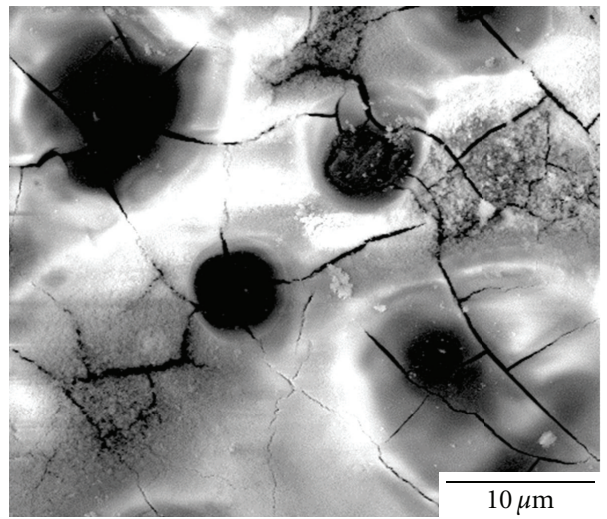

(b)

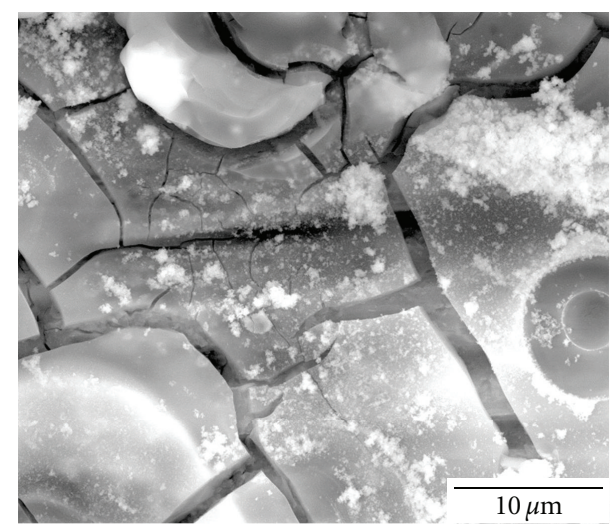

(c)

Figure 5: Surface morphology of coatings deposited on panels rinsed at $25^{\circ} \mathrm{C}$ after immersion in the coating solution for (a) 2 min, (b) $5 \mathrm{~min}$, and (c) $8 \mathrm{~min}$. 


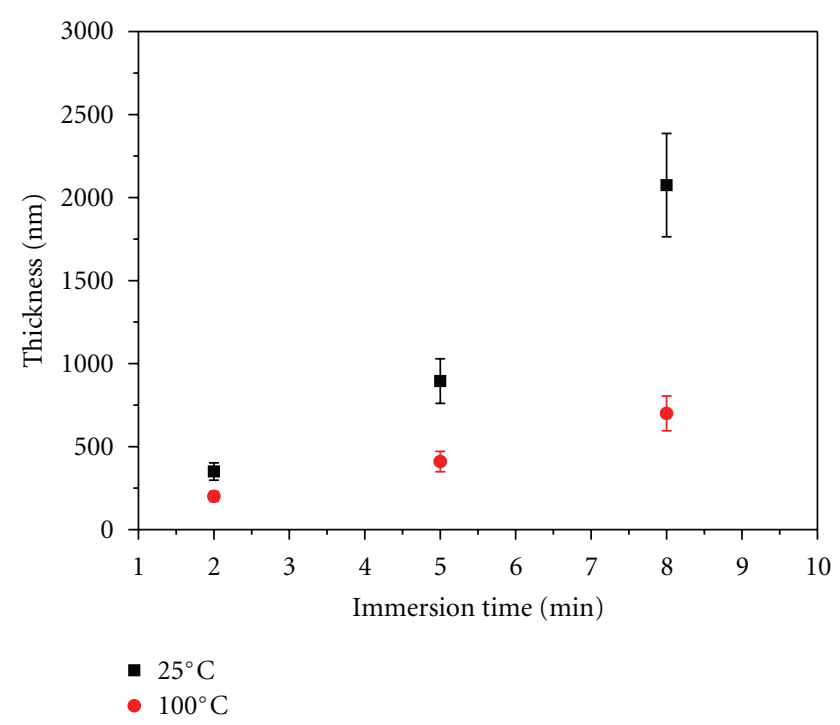

Figure 6: Thickness as a function of immersion time for CeCCs deposited on panels rinsed at $25^{\circ} \mathrm{C}$ and $100^{\circ} \mathrm{C}$.

appears to produce CeCCs on AA 380 with better corrosion resistance.

The EIS results as a function of immersion time were consistent with potentiodynamic analysis (Table 2). Rinsing at $25^{\circ} \mathrm{C}$ prior to deposition resulted in coatings with impedance values that decreased as immersion time increased (Figure $3(\mathrm{~b})$ ). For panels rinsed at $25^{\circ} \mathrm{C}$ prior to coating, the impedance was $32 \mathrm{k} \Omega \cdot \mathrm{cm}^{2}$ after 2 minutes of immersion in the coating solution and the value decreased to $16 \mathrm{k} \Omega \cdot \mathrm{cm}^{2}$ after 5 minutes and $10 \mathrm{k} \Omega \cdot \mathrm{cm}^{2}$ after eight minutes. However, for panels rinsed at $100^{\circ} \mathrm{C}$ prior to coating deposition, the impedance was $36 \mathrm{k} \Omega \cdot \mathrm{cm}^{2}$ after immersion in the coating solution for 2 minutes, and it increased to $49 \mathrm{k} \Omega \cdot \mathrm{cm}^{2}$ after 5 minutes and $79 \mathrm{k} \Omega \cdot \mathrm{cm}^{2}$ after 8 minutes (Figure $4(\mathrm{~b})$ ). For panels rinsed at $100^{\circ} \mathrm{C}$ prior to coating deposition, the impedance of $79 \mathrm{k} \Omega \cdot \mathrm{cm}^{2}$ after 8 minutes of immersion in the coating solution was more than double the highest value for coatings deposited on panels rinsed at $25^{\circ} \mathrm{C}$, which was $32 \mathrm{k} \Omega \cdot \mathrm{cm}^{2}$ after 2 minutes of immersion in the coating solution. These results indicate that rinsing at $25^{\circ} \mathrm{C}$ prior to deposition led to corrosion resistance that decreased with increasing immersion time in the coating solution whereas rinsing at $100^{\circ} \mathrm{C}$ prior to coating deposition led to corrosion resistance that increased with the increasing immersion time.

3.3. Morphology and Thickness of the CeCCs. Coatings that were deposited on panels rinsed at $25^{\circ} \mathrm{C}$ were cracked and had large holes. As shown in Figure 5, the cracks became larger as coating time increased. In addition to the cracks, large holes (dark areas), $\sim 5 \mu \mathrm{m}$ in diameter, were also observed on the panel surfaces. Even though the coatings were cracked, the average thickness (Figure 6) in areas with coating increased as immersion time increased. For example, the coating thickness was about $350 \mathrm{~nm}$ after $2 \mathrm{~min}$, but increased to nearly $2 \mu \mathrm{m}$ after $8 \mathrm{~min}$ of immersion in the coating solution. However, the thickness was not uniform and varied across the panel. The surface morphology supports the electrochemical testing results that showed that the coating impedance decreased as immersion time increased for coatings on substrates rinsed at $25^{\circ} \mathrm{C}$. As coating time increased, the size of cracks grew, which exposed more of the substrate to the coating solution and allowed for attack of the substrate. The impedance approached a value of $10 \mathrm{k} \Omega \cdot \mathrm{cm}^{2}$ for deposition times of $8 \mathrm{~min}$, which was about one-third of the value $\left(32 \mathrm{k} \Omega \cdot \mathrm{cm}^{2}\right)$ after immersion for 2 minutes. Hence, SEM analysis was consistent with electrochemical results that showed coatings deposited on substrates rinsed at $25^{\circ} \mathrm{C}$ did not serve as effective barriers to corrosion due to nonuniform coverage of the AA 380 surface.

Coatings that were deposited on substrates that were rinsed at $100^{\circ} \mathrm{C}$ had a nodular appearance (Figure 7) for all deposition times, which is similar to what has been reported in previous work [13]. The coatings covered the substrates and only a few, small cracks were observed. As with coatings on substrates rinsed at $25^{\circ} \mathrm{C}$, the thickness of CeCCs deposited on substrates that were rinsed at $100^{\circ} \mathrm{C}$ increased with increasing deposition time. After 2 minutes of immersion, the coating thickness was just over $200 \mathrm{~nm}$ and it increased to $\sim 700 \mathrm{~nm}$ after immersion for $8 \mathrm{~min}$ (Figure 6). Despite being approximately twice as thick as CeCCs on high-strength aluminum alloys, such as $\mathrm{Al} 2024-\mathrm{T} 3$ and $\mathrm{Al}$ $7075-$ T6 $[28,29]$, the coatings had only a few small cracks. As shown by the electrochemical analysis in Figure 4(b), coating impedance increased as immersion time increased, which is consistent with the formation of a thicker, continuous coating. Therefore, the surface morphology and thickness of the coatings are consistent with the electrochemical results, which showed that coatings on substrates that were rinsed at $100^{\circ} \mathrm{C}$ increased the impedance compared to uncoated substrates.

3.4. Corrosion Protection. Cerium-based conversion coatings had a yellow-gold appearance (Figures 8(a) and 9(a)) after posttreatment. After salt spray testing, coatings deposited on substrates rinsed at $25^{\circ} \mathrm{C}$ prior to immersion showed a significant amount of white corrosion produce (i.e., salting). Corrosion pits and salt tails were visible after just 24 hours in salt spray testing as shown in Figure 8(b). Coatings continued to degrade with further time in salt spray testing (Figures 8(c) and 8(d)). In contrast, coatings deposited on substrates rinsed at $100^{\circ} \mathrm{C}$ prior to deposition showed better corrosion resistance. After 24 hours, a few corrosion pits were present (Figure 9(b)), but significant salting was not observed until after 192 hours of salt spray testing. Therefore the results of salt spray testing were consistent with electrochemical characterization and surface morphology. Coatings deposited on substrates that were rinsed at $25^{\circ} \mathrm{C}$ prior to immersion had higher corrosion currents, lower impedance values, and were cracked, which led to more severe corrosion in salt spray testing. However, coatings that were deposited on substrates that were rinsed at $100^{\circ} \mathrm{C}$ prior to deposition had lower corrosion currents, higher impedance values, and were free of large cracks. As a result, coatings deposited on substrates rinsed at $100^{\circ} \mathrm{C}$ provided improved corrosion protection for AA 380 alloy substrates. 


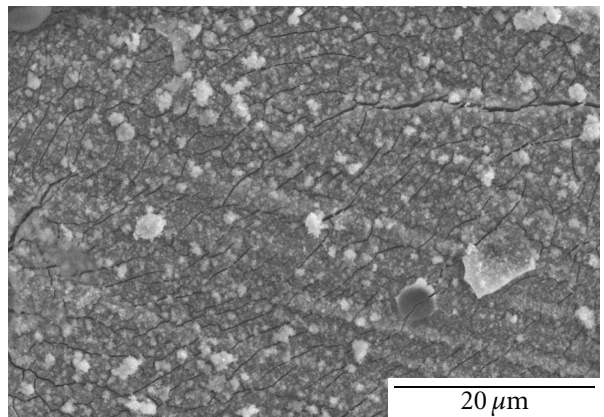

(a)

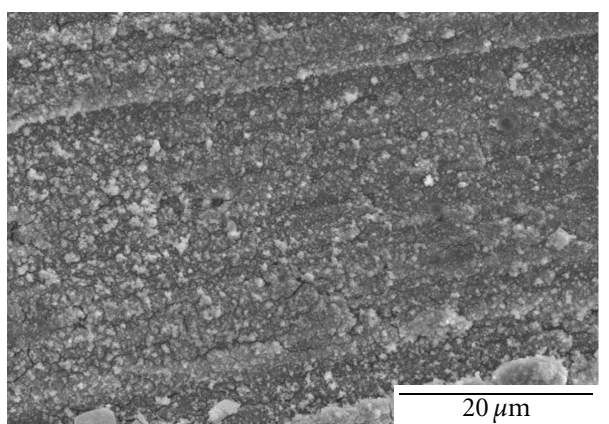

(b)

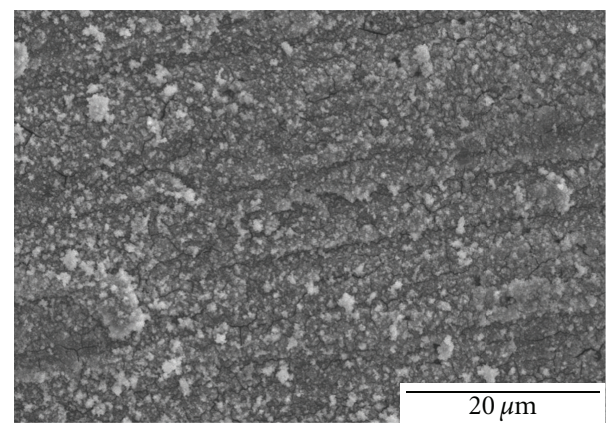

(c)

Figure 7: Surface morphology of coatings deposited on panels rinsed at $100^{\circ} \mathrm{C}$ after immersion in the coating solution for (a) 2 min, (b) $5 \mathrm{~min}$, (c) $8 \mathrm{~min}$.

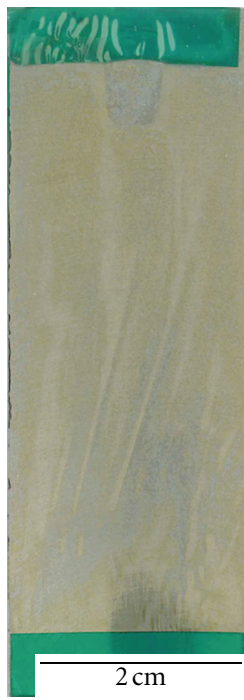

(a)

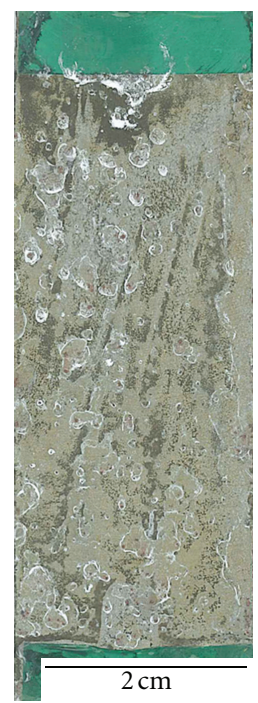

(b)

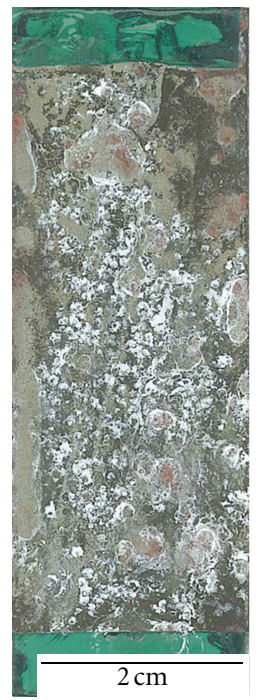

(c)

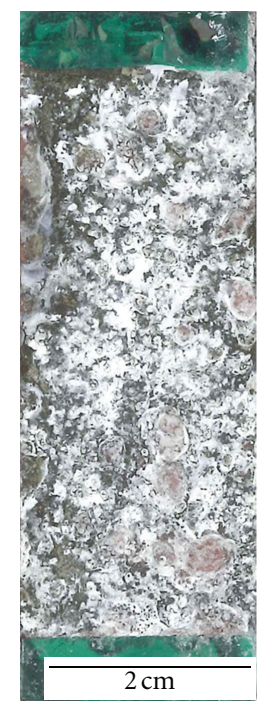

(d)

FIGURE 8: Optical images of coatings deposited on substrates rinsed at $25^{\circ} \mathrm{C}$ (a) as deposited, and after salt spray testing for (b) 24 hours, (c) 96 hours, and (d) 192 hours.

\section{Summary}

Cerium-based conversion coatings were deposited on AA 380 alloy substrates. This study examined the effect of changing the rinsing temperature prior immersion in the coating solution on the electrochemical response, coating morphology, and corrosion resistance of CeCCs. From the results described above, the conclusions that can be drawn include the following.

(1) Differences in the rinsing temperature did not produce any noticeable differences in the morphology of the substrates prior to coating or the electrochemical response of the panels prior to coating. Based on 


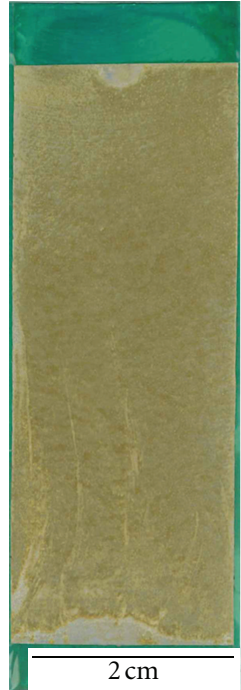

(a)

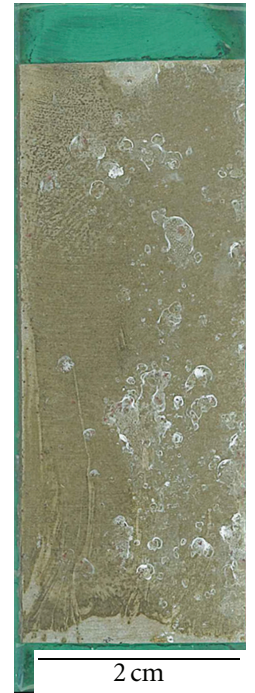

(b)

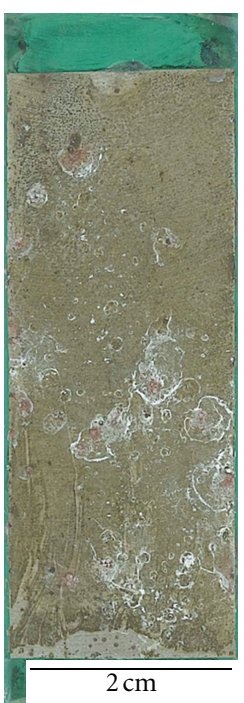

(c)

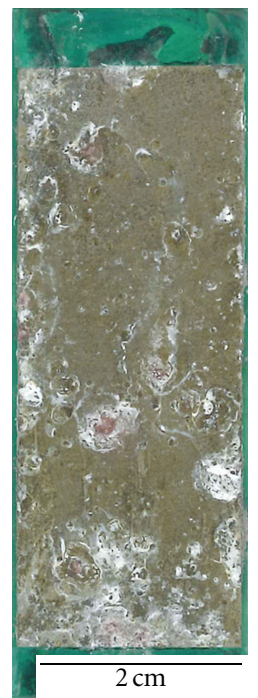

(d)

Figure 9: Optical images of coatings deposited on substrates rinsed at $100^{\circ} \mathrm{C}$ (a) as deposited, and after salt spray testing for (b) 24 hours, (c) 96 hours, and (d) 192 hours.

SEM/EDS analysis, pretreatment led to the removal of $\mathrm{Fe}$ and Si-rich intermetallic compounds from the substrate surfaces, but the open-circuit potential $\left(-500 \mathrm{mV}_{\mathrm{SCE}}\right)$, corrosion current $\left(2 \mu \mathrm{A} / \mathrm{cm}^{2}\right)$, and impedance $\left(7.5 \mathrm{k} \Omega \cdot \mathrm{cm}^{2}\right)$ of the pretreated panels were nearly identical regardless of the final rinsing temperature.

(2) Coatings deposited on panels rinsed at $25^{\circ} \mathrm{C}$ had cracks and large holes in the CeCCs. The cracks and holes became larger and deeper with increasing immersion time. The surface morphology was consistent with results of the electrochemical tests. For example, immersion for two minutes resulted in a corrosion current of $0.82 \mu \mathrm{A} / \mathrm{cm}^{2}$ and an impedance of $32 \mathrm{k} \Omega \cdot \mathrm{cm}^{2}$. As the coating deposition time increased to 5 minutes, the cracks become bigger and large holes appeared. This resulted in a corrosion current that increased to $1.6 \mu \mathrm{A} / \mathrm{cm}^{2}$ and an impedance that decreased to $16 \mathrm{k} \Omega \cdot \mathrm{cm}^{2}$. After 8 minutes of immersion in the coating solution, the coating had even lower values of corrosion current $\left(2.7 \mu \mathrm{A} / \mathrm{cm}^{2}\right)$ and impedance $\left(10 \mathrm{k} \Omega \cdot \mathrm{cm}^{2}\right)$.

(3) Rinsing at $100^{\circ} \mathrm{C}$ prior to coating deposition resulted in coatings that had uniform appearance and fewer cracks. With increasing immersion time, the thickness of the coatings increased uniformly, which enhanced the corrosion resistance. From electrochemical testing, immersion for 2 minutes in the deposition solution produced a corrosion current of $0.73 \mu \mathrm{A} / \mathrm{cm}^{2}$ and an impedance of $36 \mathrm{k} \Omega \cdot \mathrm{cm}^{2}$ with a coating thickness of $\sim 200 \mathrm{~nm}$. Increasing the coating deposition time to 5 minutes increased the thickness of the coating to $\sim 400 \mathrm{~nm}$, decreased the corrosion current to $0.54 \mu \mathrm{A} / \mathrm{cm}^{2}$, and increased the impedance to $49 \mathrm{k} \Omega \cdot \mathrm{cm}^{2}$. Further increasing the immersion time to 8 minutes increased the coating thickness to $\sim 750 \mathrm{~nm}$, decreased the corrosion current to $0.34 \mu \mathrm{A} / \mathrm{cm}^{2}$, and increased the impedance to $76 \mathrm{k} \Omega \cdot \mathrm{cm}^{2}$. Apparently, the higher rinsing temperature led to more uniform nucleation and growth of the resulting $\mathrm{CeCC}$, which decreased the corrosion current and increased the impedance compared to similar coatings deposited on substrates rinsed at $25^{\circ} \mathrm{C}$.

(4) Cerium-based conversion coatings deposited on AA 380 panels that were rinsed in water heated to $100^{\circ} \mathrm{C}$ after pretreatment, but before CeCC deposition provided significant corrosion resistance. Whereas coatings deposited on substrates rinsed at $25^{\circ} \mathrm{C}$ had both pits and salt tails after only 24 hours in salt spray testing, coatings deposited on substrates rinsed at $100^{\circ} \mathrm{C}$ were able to inhibit formation of salt tails for at least 96 hours. The improved corrosion performance of CeCCs on substrates that were rinsed at $100^{\circ} \mathrm{C}$ was attributed to the more uniform coating that was deposited, which led to higher impedance and lower corrosion currents.

\section{Acknowledgments}

The authors acknowledge the technical guidance and support of Bruce Sartwell at the Strategic Environmental Research and Development Program (SERDP). This work was funded through SERDP under Contract W912HQ-08-C-0008 as Project WP-1618. The assistance of Clarissa Wisner (SEM), Dr. Elizabeth Kulp (FIB), Dr. Kai Song (FIB), and Carlos Castano (FIB) from the Graduate Center for Materials Research at Missouri S\&T is acknowledged. 


\section{References}

[1] J. G. Kaufman and E. L. Rooy, Aluminum Alloy Castings: Properties, Processes, and Applications, American Society for Materials International, Materials Park, Ohio, USA, 2004.

[2] J. E. Hatch and Aluminum:, Properties and Physical Metallurgy, American Society for Materials International, Materials Park, Ohio, USA, 1984.

[3] J. R. Davis, Corrosion of Aluminum and Aluminum Alloys, American Society for Materials International, Materials Park, Ohio, USA, 1999.

[4] E. H. Hollingsworth and H. Y. Hunsicker, Corrosion, vol. 13 of ASM Handbook, American Society for Materials International, Materials Park, Ohio, USA, 1990.

[5] S. S. Wise, J. H. C. Schuler, A. L. Holmes et al., "Comparison of two particulate hexavalent chromium compounds: barium chromate is more genotoxic than lead chromate in human lung cells," Environmental and Molecular Mutagenesis, vol. 44, no. 2, pp. 156-162, 2004.

[6] http://www.osha.gov/SLTC/hexavalentchromium/index.html.

[7] H. J. Gibb, P. S. J. Lees, P. F. Pinsky, and B. C. Rooney, "Lung cancer among workers in chromium chemical production," American Journal of Industrial Medicine, vol. 38, no. 2, pp. 115126, 2000.

[8] R. G. Buchheit and A. E. Hughes, "Chromate and chromatefree conversion coatings," in Corrosion: Fundamentals, Testing and Protection, vol. 13A of ASM Handbook, pp. 720-735, American Society for Materials International, Materials Park, Ohio, USA, 2003.

[9] B. Meyers and S. Lynn, Surface Engineering, vol. 5 of ASM Handbook, American Society for Materials International, Materials Park, Ohio, USA, 1990.

[10] D. Zhao, J. Sun, L. Zhang, Y. Tan, and J. Li, "Corrosion behavior of rare earth cerium based conversion coating on aluminum alloy," Journal of Rare Earths, vol. 28, no. 1, pp. 371$374,2010$.

[11] G. R. Salazar-Banda, S. R. Moraes, A. J. Motheo, and S. A. S. MacHado, "Anticorrosive cerium-based coatings prepared by the sol-gel method," Journal of Sol-Gel Science and Technology, vol. 52, no. 3, pp. 415-423, 2009.

[12] B. R. W. Hinton, D. R. Arnott, and N. E. Ryan, "Cerium conversion coatings for the corrosion protection of aluminum," Materials Forum, vol. 9, no. 3, pp. 162-173, 1986.

[13] B. R. W. Hinton, "Corrosion inhibition with rare earth metal salts," Journal of Alloys and Compounds, vol. 180, no. 1-2, pp. 15-25, 1992.

[14] D. K. Heller, Phosphate post-treatment of cerium-based conversion coatings on Al 2024-T3 [Ph.D. dissertation], Missouri University of Science and Technology, 2010.

[15] S. Joshi, E. A. Kulp, W. G. Fahrenholtz, and M. J. O'Keefe, "Dissolution of cerium from cerium-based conversion coatings on $\mathrm{Al} 7075-\mathrm{T} 6$ in $0.1 \mathrm{M} \mathrm{NaCl}$ solutions," Corrosion Science, vol. 60, pp. 290-295, 2012.

[16] S. Geng, W. R. Pinc, P. Yu et al., "Influence of cleaning on the deposition rate of cerium based conversion coatings on $\mathrm{Al}$ alloy 2024-T3," Journal of Applied Surface Finishing, vol. 2, no. 4, pp. 276-282, 2007.

[17] W. Pinc, S. Geng, M. O'Keefe, W. Fahrenholtz, and T. O'Keefe, "Effects of acid and alkaline based surface preparations on spray deposited cerium based conversion coatings on $\mathrm{Al}$ 2024T3," Applied Surface Science, vol. 255, no. 7, pp. 4061-4065, 2009.
[18] D. K. Heller, W. G. Fahrenholtz, and M. J. O’Keefe, “The effect of post-treatment time and temperature on ceriumbased conversion coatings on Al 2024-T3," Corrosion Science, vol. 52, no. 2, pp. 360-368, 2010.

[19] W. Pinc, P. Yu, M. O'Keefe, and W. Fahrenholtz, "Effect of gelatin additions on the corrosion resistance of cerium based conversion coatings spray deposited on Al 2024-T3," Surface and Coatings Technology, vol. 203, no. 23, pp. 3533-3540, 2009.

[20] B. F. Rivera, B. Y. Johnson, M. J. O’Keefe, and W. G. Fahrenholtz, "Deposition and characterization of cerium oxide conversion coatings on aluminum alloy 7075-T6," Surface and Coatings Technology, vol. 176, no. 3, pp. 349-356, 2003.

[21] S. Geng, P. Yu, M. J. O’Keefe, W. G. Fahrenholtz, and T. J. O'Keefe, "Screening study of spray solution parameters for depositing cerium-based conversion coatings on $\mathrm{Al}$ alloy 2024-T3," Journal of Applied Electrochemistry, vol. 40, no. 3, pp. 551-559, 2010.

[22] B. R. W. Hinton and L. Wilson, "The corrosion inhibition of zinc with cerous chloride," Corrosion Science, vol. 29, no. 8, pp. 967-985, 1989.

[23] S. A. Hayes, P. Yu, T. J. O'Keefe, M. J. O’Keefe, and J. O. Stoffer, "The phase stability of cerium species in aqueous systems. I. E-pH diagram for the $\mathrm{Ce}-\mathrm{HClO}_{4}-\mathrm{H}_{2} \mathrm{O}$ system," Journal of the Electrochemical Society, vol. 149, no. 12, pp. C623-C630, 2002.

[24] F. H. Scholes, C. Soste, A. E. Hughes, S. G. Hardin, and P. R. Curtis, "The role of hydrogen peroxide in the deposition of cerium-based conversion coatings," Applied Surface Science, vol. 253, no. 4, pp. 1770-1780, 2006.

[25] P. Zoltowski, "The error function for fitting of models to immittance data," Journal of Electroanalytical Chemistry, vol. 178, no. 1, pp. 11-19, 1984.

[26] J. R. Dygas and M. W. Breiter, "Variance of errors and elimination of outliers in the least squares analysis of impedance spectra," Electrochimica Acta, vol. 44, no. 24, pp. 4163-4174, 1999.

[27] C. S. Lin and S. K. Fang, "Formation of cerium conversion coatings on AZ31 magnesium alloys," Journal of the Electrochemical Society, vol. 152, no. 2, pp. B54-B59, 2005.

[28] B. L. Treu, S. Joshi, W. R. Pinc, M. J. O'Keefe, and W. G. Fahrenholtz, "Characterization of localized surface states of Al 7075-T6 during deposition of cerium-based conversion coatings," Journal of the Electrochemical Society, vol. 157, no. 8, pp. C282-C287, 2010.

[29] P. S. Jones, P. Yu, W. R. Pinc, M. J. O’Keefe, W. G. Fahrenholtz, and T. J. O'Keefe, "Spray deposition of cerium oxide-based conversion coatings on $\mathrm{Al}$ 2024-T3," International Journal of Applied Ceramic Technology, vol. 5, no. 1, pp. 63-73, 2008. 

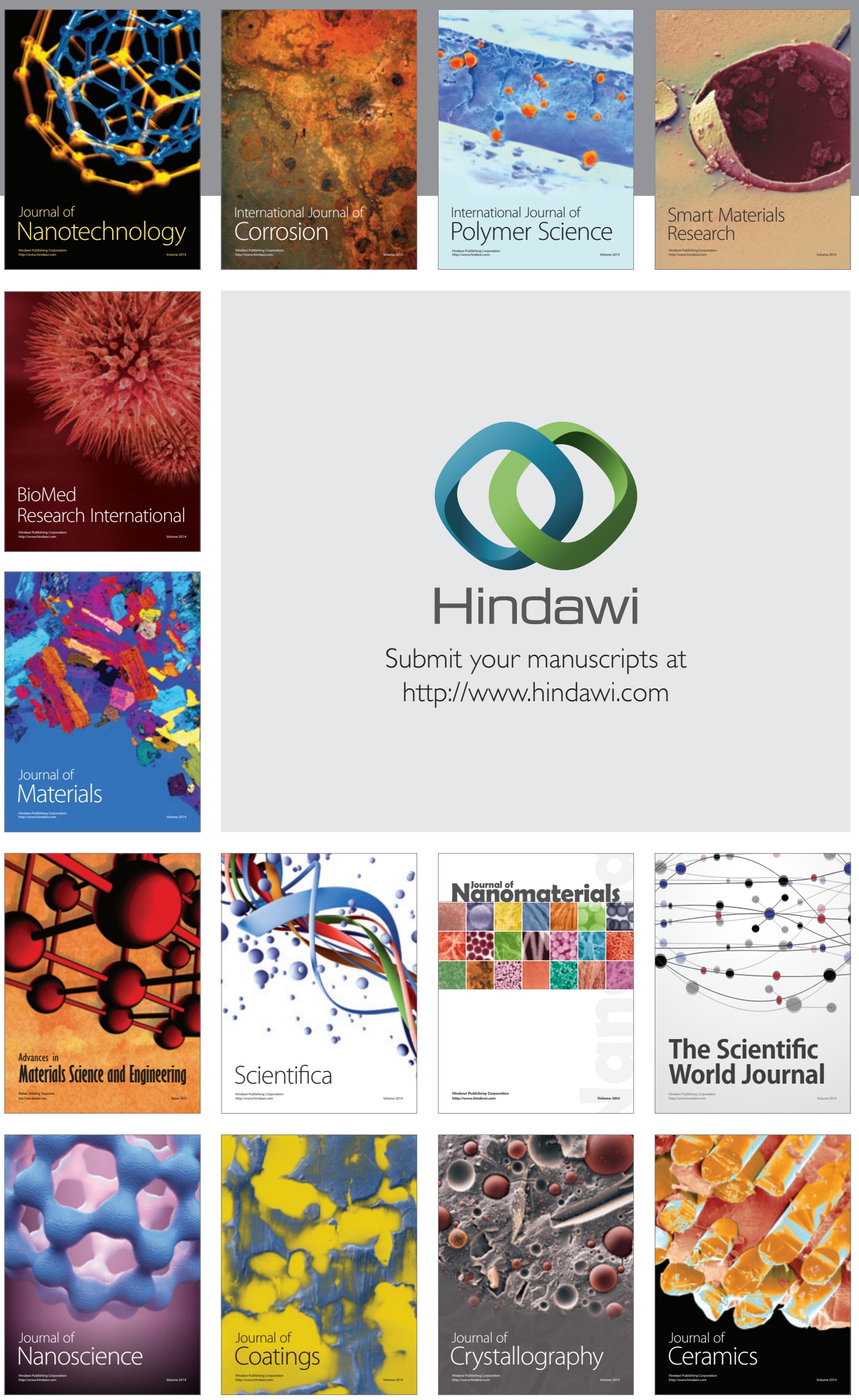

The Scientific World Journal

Submit your manuscripts at

http://www.hindawi.com

\section{World Journal}

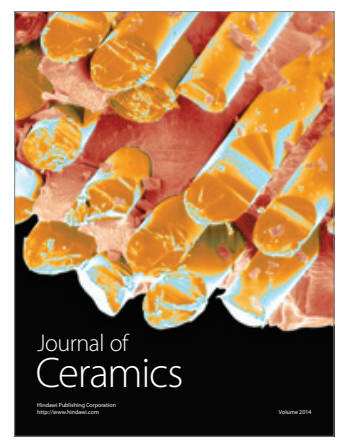

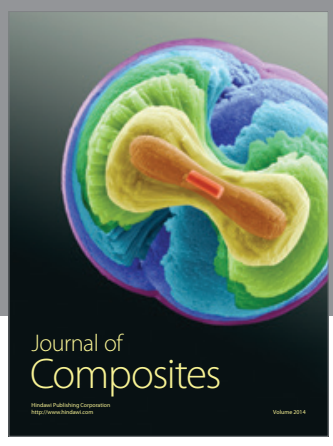
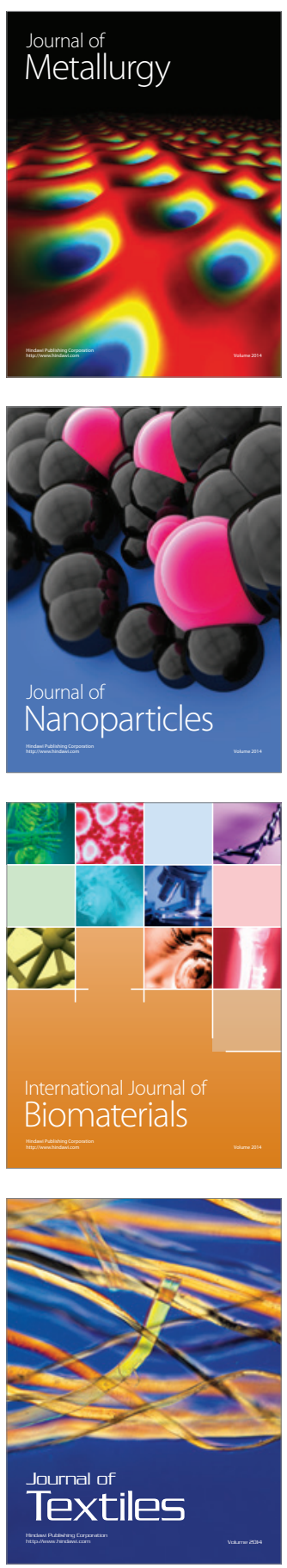